\title{
INVESTIGATION OF INSECT DYNAMICS ON FLOWERING OF IRVINGIA GABONENSIS TREES IN SOUTHERN NIGERIA: TOWARDS INDIGENOUS AGROFORESTRY TREE CROP DEVELOPMENT FOR FOOD SECURITY
}

\author{
Gloria C. Ujor PhD \\ Nigerian Environmental Study Action Team (NEST) \\ Ibadan, Oyo State, Nigeria
}

\begin{abstract}
Irvingiagabonensis (O'Rorke) Baill., is an indigenous fruit tree species of high economic importance in the forest zone of West and Central Africa. In Nigeria, it is known to have high potentials for contribution to the food security and viable food value chain. This study investigated the guilds of insect visitors to the tree species in southern Nigeria (Enugu and Ibadan) through use of fly traps for collection of insect specimens. Proper identification of the insects and determination of other parameters such as the number of days and time of visits across two sites were carried out based on observations. In addition, relative frequency of visits, across the tree crown strata were also compared. Analysis of variance on the various parameters showed that the number of days of visit and the three periods of the day were significantly different respectively at $5 \%$ level of probability. The study also showed that there were homogenous insect populations in southern Nigeria, thus contributing information to the breeding potentials of the species. The insect order Hymenoptera appeared most prevalent of all insect order populations in this investigation. Pollinating agents, if known, will contribute to the breeder's choice in carrying out trials on indigenous species like I. gabonensis, which is being recommended for further and improved cultivation trials towards adding to the food security and food value chain in Nigeria.
\end{abstract}

Key words: Flowering, Irvingia gabonensis, indigenous economic tree, insect classification, visitation frequency

https://dx.doi.org/10.4314/jafs.v15i2.3

\section{INTRODUCTION}

Journal of the Faculty of Agriculture and Veterinary Medicine, Imo State University Owerri website: wwwajol.info 
Recently, indigenous economic trees found naturally in the farming systems of Southern Nigeria compete with the usual cash, sometimes exotic crops in terms of importance, recognition and demand. About 30 years ago, the trees were in their natural high forest areas (Anonymous, 2006). But today efforts have been made to grow them consciously in modern farms and their domestic cultivation is in addition being improved. Irvingia gabonensis belongs to such indigenous trees. The species of reference, also described in Ujor, (2016), is widely known because of its edible fruit pulp in addition to its cotyledons that form part of an international market commodity. The tree species is indigenous to West and Central African forests and farming systems. And its products are traded both nationally and internationally across the countries of these regions. Furthermore, using the people's value index, the species had been ranked amongst the first five important indigenous fruit trees in Nigeria, contributing to the view of Akinnefesi, Ajayi,Sileshi, Kadzere, \&Akinnefesi(2007) that I. gabonensis has high expected rate of adoption by community farmers. Taxonomically, the species belongs to the family IRVINGIACEAE of the order MALPHIGIALES, and some other species within the family are well recognized, especially, Irvingia wombolu.

An attempt was made to study insect dynamics with respect to various groups of insects that visit this tree species during the flowering phase. Already it is reported that there is pollination linkage between canopy flowering and bumble bees, which invariably contribute to seed production, (Inari, Hiura, Toda \&Kudo, 2012). Ordinarily it is believed that information on insect dynamics on this species during bloom will contribute to the breeders' choice of interventions that will involve breeding programmes on Irvingia species. This is in addition to the fact that Whitmore (1999), indicated that combinations of flower and inflorescence features which attract particular pollinators, occur in all parts of the tropics. It is also argued that for thorough diversification in addressing food security in Nigeria, recognition should be given to the less known indigenous species which have hitherto been in the background, but which forms almost the main source of nutrition for the locals. Irvingiagabonensis has even transcended that level since it is widely consumed across various countries. Interestingly, AIT 12 noon News of $21^{\text {st }}$ February, 2017 emphasized the use of indigenous research findings for the good of Africa. It further added that looking inwards into the natural breeding systems of our indigenous crops for proper placement within the context of our food security drives is of utmost importance. For this study, two sites in southern Nigeria, Enugu and Ibadan were chosen, for comparative analysis and for proper scientific identification of the insect specimens. 
The objective of this study was to investigate various aspects of insect occurrence at specified periods of the blooming days of Irvingia gabonensis in two sites in southern Nigeria, in addition to the frequency of visits of the different insect orders.

\section{RESEARCH METHODS \\ Study Sites}

The investigation was carried out in southern Nigeria (Figure 1) at Enugu and Ibadan. Being in different agro-ecological zones, these two sites ordinarily show differences mainly in edaphic and climate characteristics. Enugu, in Enugu state lies within the derived savanna (southern Guinea savanna) in the south east geopolitical zone of Nigeria. Its geographical coordinates are $7^{\circ} 31^{\prime \prime E a s t ~ a n d ~} 6^{\circ} 27^{\prime \prime}$ North. The rainfall and temperature average values are $1600 \mathrm{~mm}$ and $27^{\circ} \mathrm{C}$ respectively (NIMET, 2014). The soil type is ferralitic. Ibadan, Oyo state is on the geographical coordinates of $3^{0} 56^{\prime}$ East and $7^{0} 20^{\prime}$ North, within the south-west geopolitical zone of Nigeria. The ecology is dry forest zone. The rainfall and temperature average values are $1193 \mathrm{~mm}$ and $28^{\circ} \mathrm{C}$ respectively (NIMET, 2014) with sandy loam soil type. According to the FAO, (19932007), I. gabonensis reportedly is present in the tropical wet and dry forest zones. The locations were chosen on the basis of identification of the trees of Irvingia species amongst the population of the tree species in the vicinity. In addition, for comparative analysis, it was considered important to choose locations in different ecological zones where the tree species were found.

\section{Tree Selection}

This was done randomly based on accessibility to the bases and crowns of the trees found within wild populations of other tree species in the two locations. Due to the difficulty of having ample choice of trees, insect activities on one blooming Irvingia gabonensis tree per site was investigated.

\section{Identification and classification of insect visitors to Irvingia gabonensis at bloom of two mixed populations collected from Enugu and Ibadan}

Flytraps of dimension $35 \mathrm{~cm}$ diameter and $80 \mathrm{~cm}$ depth were used to collect insect specimens that visit Irvingiagabonensis at specific times in the two locations of study. To ensure uniformity in the collection exercise, one swoop per period per day was done on the tree species in the two locations for three days. In each location, insects caught after each period were demobilized with insecticides and kept serially according to the periods of catch. The specimens collected at 
Enugu were transported to Ibadan at the end of the three days of catch. At Ibadan, the two populations (Enugu and Ibadan) of the insect specimens were mixed after observing homogeneity of the samples collected at the two sites, prior to scientific identification and classification in the Entomology section of the Forestry Research Institute of Nigeria (FRIN). Proper scientific name was then given to each insect by entomologists at the FRIN Entomology section laboratory. The classification of the identified specimens was done from the higher phylum classification of order to family, then to genus and the species, since all insects already belong to one Class of INSECTA.

\section{Determination of the Intensity of Insect Visits at the Different Days of Flower Bloom}

Starting from the day of observed anthesis, insect populations in the two sites were caught during three hourly periods of $06.00-08.00,12.00-14.00$ and $16.00-18.00$ per day, for 5 days in two swoops, per period per day, to ensure uniformity in comparison between the two sites and amongst the 5 days. This investigation was carried out in the two sites. A simple count of the insect populations caught at the 3 different day periods for days 1, 2, 3, 4 and 5 was tabulated. The mean value was calculated for each period across the five days and then analysed between the sites, amongst the days and amongst the periods in order to understand the differences observed in the mean values.

\section{Determination of the Intensity of Visits of the Different Insect Orders to Irvingia gabonensis}

The insect specimens which were identified and classified at the entomology laboratory of the FRIN, were grouped according to the phylum orders of the Class Insecta, and counted numerically. The numerical figures were converted to percentage values, of the different insect orders before making a graphical presentation to inform on the major and minor populations of insect order visitors to the tree species during flowering periods. This investigation was carried out in Ibadan.

\section{Determination of the Relative Frequency of Insect Occurrence on Irvingia gabonensisTree Crown Strata}

The same size of flytraps were used to randomly collect insect visitors across the lower, the middle and the upper strata respectively in two swoops per stratum on day 2 only, between the hours of 12.00 and 14.00. The services of tree climbers were used for collection from the three strata. The insects were demobilized with insecticide before the numerical values of each flytrap 
was assessed. The values were then expressed graphically after conversion to percentage values. This investigation was done using one tree of I. gabonensis which has an estimated height of ten metres and crown depth also estimated as five metres, in Enugu.

\section{RESULTS AND DISCUSSIONS}

\section{Insect Visitors to Irvingia gabonensis at Bloom, their Identification and Classification}

A total of 39 insect species groups were identified and classified as shown in Table 1. The classification grouped the insects into eight orders and 24 families. In Table 1, it is observed that the insect groups from the orders Diptera and Hymenoptera were more in population. The Diptera had eight families, while the Hymenoptera had four families. The Coleoptera had four families too but with less population of insect species. From this observation, members of the Diptera and Hymenoptera appeared as main insect species that visited Irvingia gabonensis during bloom in the locations, and as at the time of this investigation. In a similar study, Dhaliwal and Arora (2010), indicated that the most diverse order of insects based on the species described, are the Coleoptera, followed by the Lepidoptera, the Hymenoptera and the Diptera. In addition, I. gabonensis has been reported by the World Agroforestry Center, to be pollinated by the Coleoptera, the Diptera, the Hymenoptera and the Lepidoptera. It is therefore envisaged that no particular level of intensity can be attributed to any of the orders, and other site factors can contribute to the intensity levels of visitation of the different insect orders.

\section{Intensity of Insect Visit at the Different Days of Flower Bloom in two Sites of Southern Nigeria}

The mean insect visitor count on flowering Irvingia gabonensis trees collected at three different periods of the day (06.00-08.00, 12.00-14.00 and 16.00-18.00hour) in Enugu and Ibadan is presented in Table 2. Ordinarily, discrepancies were seen in the figure values in days 1,2,3,4 and 5 during the three hourly periods per day, but no consistent pattern could be ascertained. It was also observed that there was higher mean value of the population in Ibadan than that of Enugu on day 5 , while for days $1,2,3$ and 4 , the reverse was the case.

The mean values between the sites, amongst the days and amongst the periods of the day were analyzed, as shown in Table 3. From the analysis, there was no significant difference between the populations of insects that visited the tree species in the two sites, hence it can be inferred that in controlled breeding programs, the same or similar populations of insect species are expected to pollinate the species in any of the two locations. In addition, for a tree breeding 
exercise to succeed, it is important to investigate the organisms that can contribute in spreading the genes (pollen) materials from one flower to another. This was already reported for forest ecosystems, where trees produce large amounts of floral resources for pollinators, though flower production was observed to fluctuate highly from year to year, thus influencing the population dynamics of pollinators (Inari et al., 2012). Tree breeding for an indigenous agroforestry species is considered important for food security in particular when the species in question is of high economic importance, and obviously contributing to the sustenance of the livelihoods of the local communities (Akinnifesi et al., 2007). This is the case for I. gabonensis species that exists in the southern zone of Nigeria, which is likely populated with homogenous and identical insect populations, based on the observations from this study.

Table 3 also showed that the intensity of visit is significantly different amongst the 5 days of observation and catch. Floral resources have been reported (Inari et al., 2012) to develop and increase at the peak of anthesis and thereafter decrease from the day of anthesis till the flower ordinarily withers. This can be explained from the increased visit from day 1 to day 2 , followed with the sharp decline in the population visit from day 4 to day 5 in the two sites. The three periods of the day examined also showed significant difference in the population visits. This implies that insects are more active at certain times of the day than at other times based on optimum temperatures and light values, as reported in Schowalter, (2011).

Furthermore, from Table 3, all the interactions concerning the sites and the days, sites and the periods, sites and both the periods and the days were not significant respectively. In addition, the interaction of the day and the period was also not significant.

\section{Intensity of Visit of the different Insect Orders on Irvingia gabonensis}

The relative population of the different insect orders that visit Irvingia gabonensis during bloom is expressed in Figure 2. As shown in the figure, the order Hymenoptera had the highest population of visits, closely followed by the order Diptera. The order Odonata had the least number of visits. The Hymenoptera had species from the families of Apidae, Vespidae, Sphecidae and Formicidae that visited the flowers at different population levels. Apismellifera $\mathrm{L}$. of the family Apidae was a remarkable species observed, which posed greater challenge in approaching the fruiting crowns during observations because of its poisonous stings. Insect orders of Lepidoptera, Coleoptera, Hymenoptera and Hemiptera were described much earlier (Graham \& Knight, 1952), as leaf-eating and sap-sucking insects of higher plants. This implies 
that the activity of the insects goes far beyond visitation to trees at specific times when superficial presentations of the trees occur.

The description here reflects the level of insect order populations found in the vicinity of the flowering species of I. gabonensis at the time of this investigation. However, the findings in this study corroborate with Dhaliwal \& Arora, (2010), who reported that the most diverse order of insects based on the actually described species, is the Coleoptera, followed by the Lepidoptera, the Hymenoptera and the Diptera. I. gabonensis has also been reported by the World Agroforestry Center ( 2017), to be pollinated by the Coleoptera, the Diptera, the Hymenoptera and the Lepidoptera

\section{Relative Frequency of Insect species Occurrence on Irvingia gabonensis Tree Crown Strata}

The relative abundance of insect species visitors at three different strata on I. gabonensis tree crown is illustrated in Figure 3. From the percentage values illustrated in the figure, insect activity was observed to be highest in the middle stratum, followed by the lower stratum as at the time of catch (between 12.00 and 14.00 hours). It could be explained that insects flights above certain heights were difficult, hence the more concentration of flights at the middle and lower strata. In addition, it was assumed that the concentration of floral structure and resources was higher above the lower stratum probably because this stratum was not privileged to have abundant solar energy as the middle and upper strata. In the case of the low percentage value for the upper stratum, it was inferred that insect flights to heights were limited.

\section{CONCLUSION}

Indigenous tree species in the tropical ecological zones of southern Nigeria appear to routinely host a guild of insect species especially during their flowering regimes. The classification of the insect specimens in this study, showed that some insect orders are more active than others in both locations, based on ordinary population assessment. The optimum period of visitation of the insects was elucidated and this tallied with the intensity of blooming days in all the trees investigated. Similarly the insects preferred certain day periods (hourly) than others, and responded accordingly to certain levels of tree crown strata, while tending to be more active in the portion exposed more to solar radiation.

Insects are renowned occupants of the forest ecosystem, thus their efforts at the varying stages of tree development within forests are widely reported. The number of insect orders identified in this investigation showed that I gabonensis is largely pollinated by insects. Therefore, 
populations of known insect visitors to particular tree crops should be encouraged because this will enhance the breeding potential of the tree crop as is envisaged in this case, for contribution towards addressing the nation's food security.

\section{Recommendation}

A study of this nature should be followed up with further investigations, especially on similar situations. For instance, since the study was done on trees in the wild, there is the need to carry out observations on trees in orchards or such controlled breeding trials. It is therefore important to harness the potentials of indigenous economic fruit/food tree species in our farming systems, through putting more efforts to improve the available knowledge in the reproductive biology of the species, more so now that the country is looking inward to developing available local food resources to improve the food security situation and add to the country's agricultural value chain. 


\section{REFERENCES}

Akinnefesi, F.K., Ajayi, O.C., Sileshi, G., Kadzere,I. \&Akinnefesi, A.I. (2007). Domesticating and Commercialising Indigenous Fruit and Nut Tree Crops for Food Security and Income Generation in sub-Saharan Africa. Paper presented at the New Crops International Symposium. Retrieved from http://www.worldagroforestry.org

Anonymous,( 2006). Lost Crops of Africa 2. Vegetables. Washington DC. National Academic Press 2006, pp 119-135. ISBN 0-309-10333-9. In: https://en.wikipedia.org/wiki/Irvingia_gabonensis. Accessed September 2017

Dhaliwal, G.S. \& Arora, R. ( 2010). Integrated Pest Management. Reprinted Edition. Kalyani Publishers, New Delhi. 369 pp.

Graham, S.A. \& Knight, F.B. (1952). Principles of Forest Ecology. Fourth Edition. McGrawHill Book Company 417 pp.

Inari, N. Hiura, T. Toda, M.J. \& Kudo, J. (2012). Pollination Linkage between Canopy Flowering, bumble bee abundance and seed production of understory plants in a Cool Temperate Forest. Journal of Ecology 2012, 100, 1534-1543. Doi:10.1111/j 1365-2745. 2012, 03021.x. online library.wiley.com/F

Irvingia gabonensis. Agroforestry Tree Database. (2017). World Agroforestry Centrehttps://en.wikipedia.org/wiki/Irvingia gabonensis. Accessed September 2017

Irvingia gabonensis. ECOCROP.Food and Agriculture Organisation (2017).https://en.wikipedia.org/wiki/Irvingia gabonensis 1993-2007. Accessed September 2017.

Nigeria Meteorological Agency (NIMET), (2014). Quarterly Compilation of Agromet Decadals. April - June 2014. Nigeria Meteorological Agency (14), June 2014.

Schowalter, T.D. ( 2011). Insect Ecology. An Ecosystem Approach. Third Edition 625 pp. file.zums.acor/ebook/760-Insect\%Ecology.

Ujor, G.C. (2016). Comparative Analysis of Leaf Characteristics of Irvingia gabonensis and Irvingia wombolu in Southern Nigeria: Implication for Food Security and Policy in Nigeria. Nigeria Agricultural Policy Research Journal (NAPReJ) 1 (1) pp 119-128.

Whitmore, T.C.(1999). An Introduction to Tropical Rain forests. Second Edition. Oxford University Press $282 \mathrm{pp}$. 


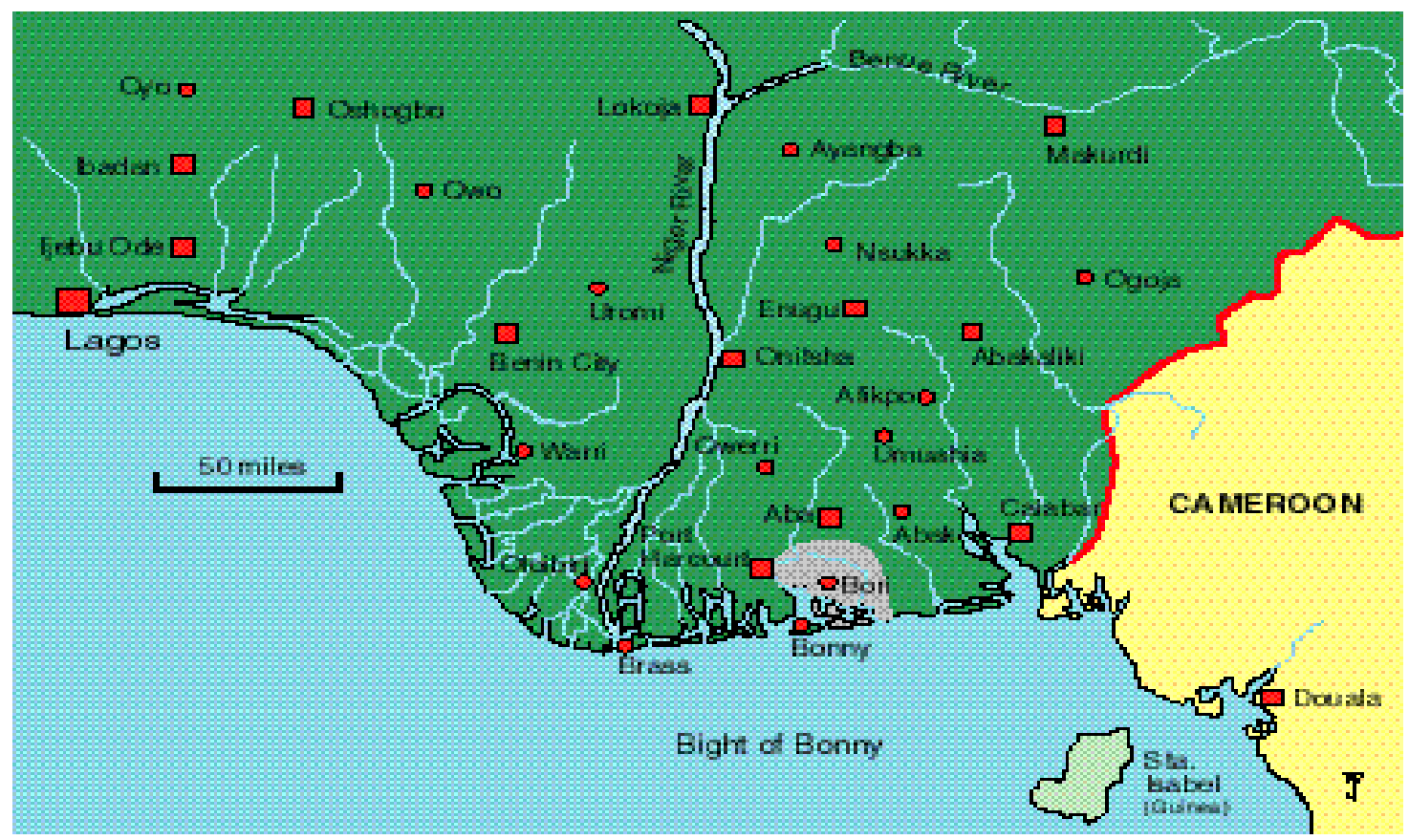

Fig 1. Map of Southern Nigeria showing Ibadan among locations on the far left, while Enugu is on the right.

Source: meniru.blogspot.com.ngaccessed July 2017.

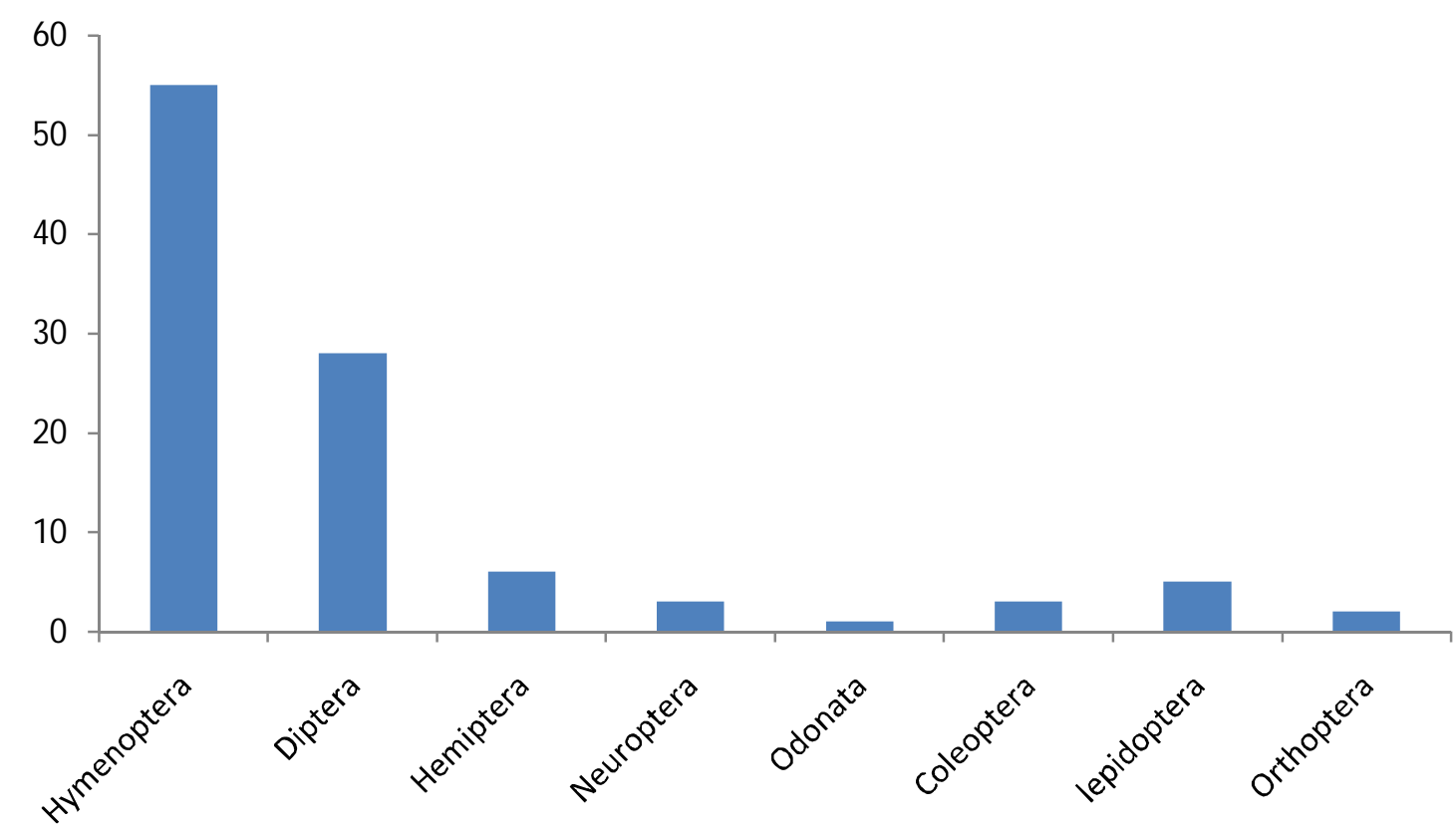

Figure 2. Relative Frequency (\%) of Insect Orders' Visit toIrvingiagabonensis at Bloom Journal of the Faculty of Agriculture and Veterinary Medicine, Imo State University Owerri website: wwwajol.info 


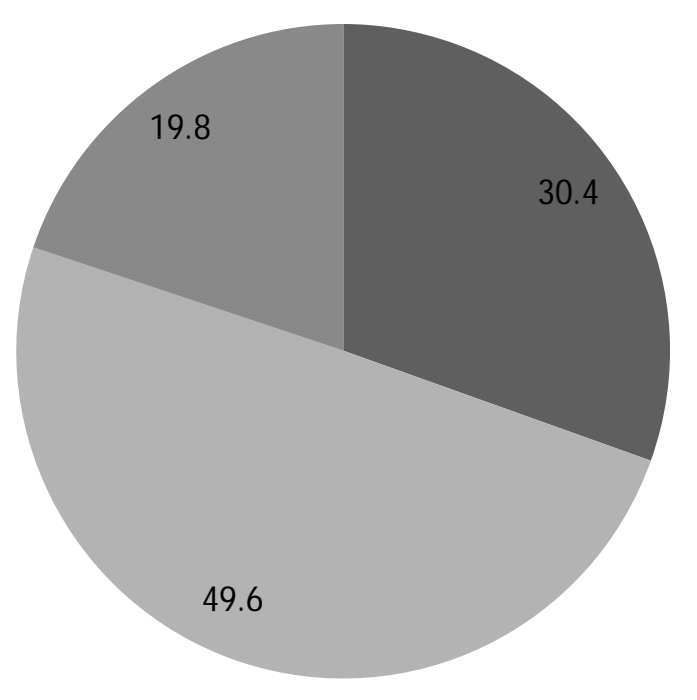

$$
\begin{aligned}
& \text { - Lower Stratum } \\
& \text { Middle Stratum } \\
& \text { Upper Stratum }
\end{aligned}
$$

Figure 3. Relative Frequency of Insects' Visits to I. gabonensis Tree Crown Strata 
Table 1: Classification of Insect species that visited Irvingia gabonensis at bloom in southern Nigeria

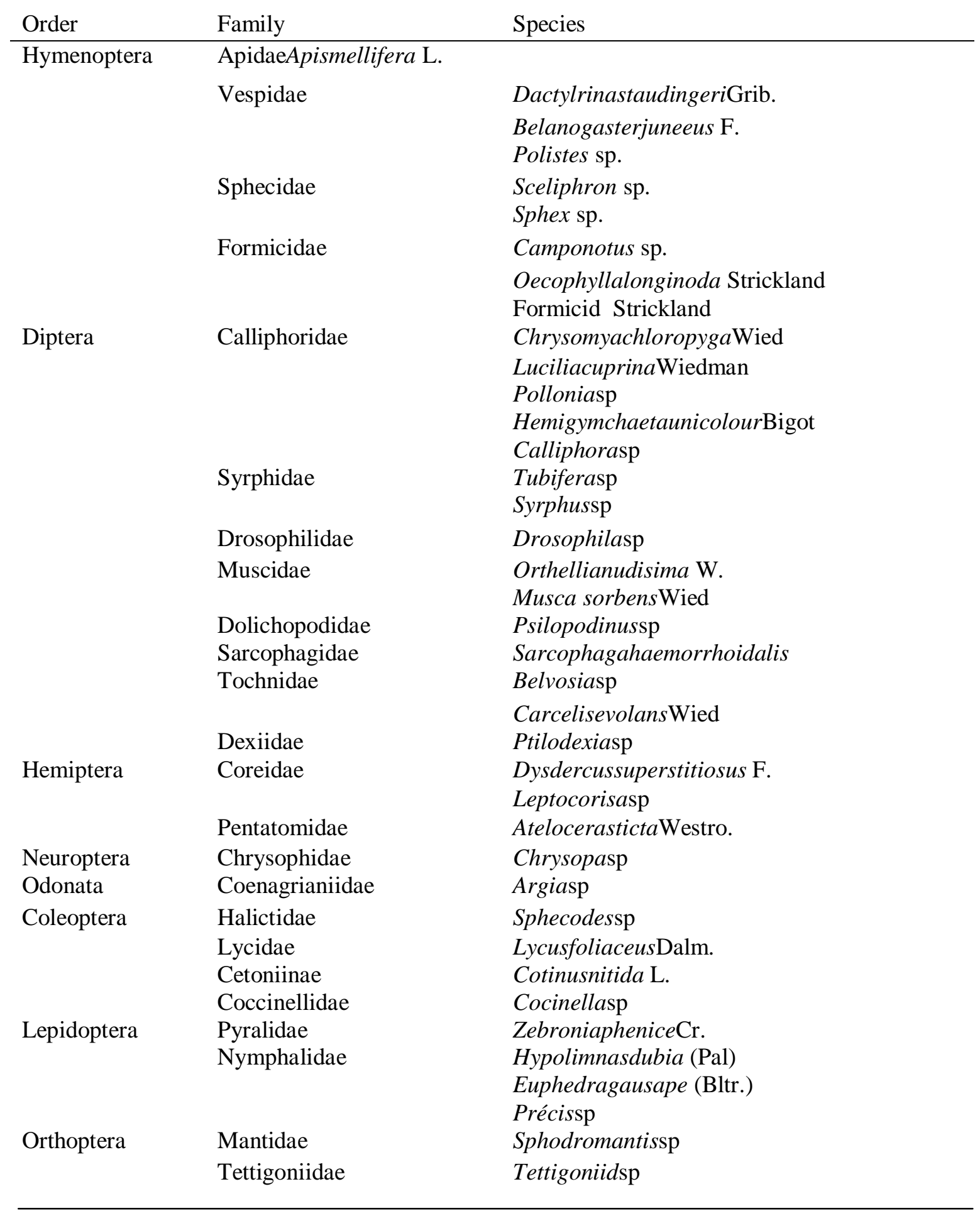

Source: Field Data Collection, 2015

Journal of the Faculty of Agriculture and Veterinary Medicine, Imo State University Owerri website: wwwajol.info 
Table 2. Mean Insect Visitor Count on Flowering Irvingiagabonensis trees in Enugu and Ibadan

\begin{tabular}{|c|c|c|c|c|}
\hline \multicolumn{2}{|c|}{ DAY } & \multicolumn{2}{|l|}{ PERIOD } & \multirow[b]{2}{*}{ Mean } \\
\hline & $06-08 \mathrm{~h}$ & $12-14 \mathrm{~h}$ & $16-18 \mathrm{~h}$ & \\
\hline \multicolumn{5}{|c|}{ I. gabonensis in Enugu } \\
\hline 1 & $419.33 \pm 21.07$ & \multicolumn{2}{|c|}{$490.33 \pm 0.00383 \pm 24.00430 .88 \pm 29.07$} & \\
\hline 2 & $560.33 \pm 19.44$ & $625 \pm 10.69$ & $86.33 \pm 18.68$ & $523.88 \pm 16.27$ \\
\hline 3 & $453.33 \pm 13.93$ & $559.66 \pm 19.04$ & $251.33 \pm 49.43$ & $421.44 \pm 41.65$ \\
\hline 4 & $113.33 \pm 7.35$ & $211 \pm 71.09$ & $72.66 \pm 17.14$ & $132.00 \pm 31.86$ \\
\hline 5 & $14.33 \pm 2.33$ & $17 \pm 7.09$ & $6 \pm 3.05$ & $12.44 \pm 3.10$ \\
\hline \multicolumn{5}{|c|}{ Mean $312.13 \pm 12.82382 .74 \pm 21.58220 .46 \pm 22.46$} \\
\hline$I$. & \multicolumn{3}{|c|}{ gabonensis in Ibadan } & \\
\hline 1 & $300.33 \pm 67.58$ & $401.33 \pm 11.35$ & $176.66 \pm 67.27$ & $292.77 \pm 48.70$ \\
\hline 2 & $317.26 \pm 17.50$ & $492.33 \pm 62.09$ & $279 \pm 12.42$ & $362.86 \pm 30.61$ \\
\hline 3 & $305.33 \pm 80.75$ & \multicolumn{2}{|c|}{$390 \pm 10.55202 .33 \pm 92.68$} & $299.22 \pm 61.82$ \\
\hline 4 & $124.33 \pm 50.84$ & $193.33 \pm 56.62$ & $64 \pm 32.41$ & $127.22 \pm 46.63$ \\
\hline 5 & \multicolumn{2}{|c|}{$23.33 \pm 15.8549 .33 \pm 18.46$} & $4.33 \pm 0.88$ & $25.99 \pm 13.01$ \\
\hline $\mathrm{Me}$ & an $214.12 \pm 46.5$ & $305.26 \pm 31.81$ & $1145.26 \pm 41.10$ & \\
\hline
\end{tabular}

Source: Field Data Collection, 2015

Journal of the Faculty of Agriculture and Veterinary Medicine, Imo State University Owerri website: wwwajol.info 
Table 3. Analysis of Variance on the effect of some factors on the visitation of 1 . gabonensis Trees by pollinators

\begin{tabular}{lcccc} 
Source of Variation & DF & MS & F-tab & Remarks \\
\hline & & & & \\
Sites1 & & & \\
& & & \\
& & & \\
Days & 4 & 608381.239 & $15.846^{*}$ & Sig \\
Period & 2 & 193980.011 & $5.053^{*}$ & Sig \\
Site X Days & 4 & 24319.961 & 0.633 & NS \\
Site X Period & 2 & 14.233 & 0.000 & NS \\
Day X Period & 8 & 12543.831 & 0.327 & NS \\
Site X Days X Period & 8 & 3246.136 & 0.85 & NS \\
Error & & & & \\
Total & 60 & 38392.400 & &
\end{tabular}

*significant at $\mathrm{p}=0.05$

Source: Field Computation 